\title{
Treatment of fulminant hepatic failure - Is there light at the end of the tunnel?
}

\author{
KDE KAITA MD FRCPC
}

KDE KAITA. Treatment of fulminant hepatic failure - Is there light at the end of the tunnel? Can J Gastroenterol 1995;9(6):319-326. A lot of research has been done on fulminant hepatic failure (FHF), mainly because of the high mortality associated with it. Many centres continue to search actively for the ideal medical treatment for FHF because liver transplantation is often difficult in these very ill patients. The many forms of therapy that have been tried and reported in case reports, small clinical trials and the occasional randomized controlled trial are reviewed, as are the current data on bioartificial livers and isolated hepatocyte transplantation. The ideal treatment remains elusive, and more work needs to be done to find a highly effective form of therapy for these very ill FHF patients.

Key Words: Fulminant hepatic failure, Treatment

Traitement de l'insuffisance hépatique fulminante : y a-t-il de la lumière au bout du tunnel?

RÉSUMÉ : L'insuffisance hépatique fulminante (IHF) a fait l'objet d'abondantes recherches, surtout à cause du fort taux de mortalité qui lui est associé. De nombreux centres continuent de chercher activement le traitement idéal de l'IHF, compte tenu du fait que la transplantation hépatique est souvent difficile chez ces grands malades. Les nombreuses formes de traitement à l'essai qui ont fait l'objet de rapports de cas sont passées en revue, tout comme les données récentes sur les foies bio-artificiels et la transplantation d'hépatocytes isolés. Le traitement idéal n'a pas encore été trouvé et il faudra approfondir encore les recherches pour arriver à traiter efficacement ces très grands malades atteints d'IHF.
$\mathrm{F}$ ULMINANT HEPATIC FAILURE (FHF) or acute liver failure is a condition defined as the development of encephalopathy within eight weeks of onset of the illness (1). Sub-FHF is defined as encephalopathy developing between two

and 12 weeks after illness onset (2) and late onset hepatic failure is encephalopathy developing between eight and 24 weeks after the illness (3). Although FHF is relatively uncommon, approximately 2000 cases are reported in the

Liver Diseases Unit, Department of Medicine, University of Manitoba, Winnipeg, Manitoba Correspondence and reprints: Dr KDE Kaita, Liver Diseases Unit, GF407, Health Sciences Centre, 820 Sherbrook Street, Winnipeg, Manitoba R3A 1R9. Telephone 204-787-4662, fax 204-775-4255

Received for publication October 11, 1994. Accepted March 10, 1995
United States annually (4), and it carries a mortality as high as 80 to $90 \%$ for stage 4 coma. As several excellent reviews have recently been written about the causes, pathophysiology and complications of FHF (4-11), this paper will review the therapeutic options that have been reported in the past, those being used now and possible therapeutic options for the future.

In brief, FHF is a life-threatening illness that results ultimately from the near complete destruction of the liver by various agents such as viruses, drugs, toxins, ischemia, genetic disorders or autoimmune disease. Survival for FHF patients has improved over the past two decades despite minimal advances in specific therapy, likely due to advances in intensive care medicine (12). Nonetheless, the search continues for treatment modalities other than liver transplantation which, although effective, has many problems associated with it. It requires a donor in an urgent situation who may not match $\mathrm{ABO}$ blood group or size, and life-long immunosuppression with all its associated complications (infection, tumours, renal dysfunction, hypertension, metabolic problems, etc). Liver transplantation is associated with a survival rate that, while improving, is still less than that of non-FHF liver failure $(13,14)$. The only exception is in patients with grades 1 to 3 coma in whom survival can be as high as $80 \%$ (15). It is also important to note that if the FHF patient 
survives without a liver transplant, he/she is left with a completely normal liver. Thus, it is imperative that more effective therapy for FHF be found.

\section{STEROIDS}

Two of the initial treatments reported for FHF were adrenalcorticotrophic hormone (ACTH) and cortisone in the 1940s and early 1950s. There are several case reports of improvements in biochemistry, appetite, jaundice and survival in patients with grade 4 hepatic encephalopathy with such therapy (16-21). Perhaps the most cited article is that by Ducci and Katz (21). Their experience prior to steroids was that no patient in stage 4 coma survived FHF. In their study, six FHF patients were treated with cortisone, ACTH and antibiotics. However, only three of the six patients had true FHF; the other three had chronic hepatitis and cirrhosis. Of the three with FHF, two survived after being in stage 4 coma for more than $48 \mathrm{~h}$. The third died $1 \mathrm{~h}$ after admission. The authors concluded that the treatment might have been effective by decreasing the extent of hepatic inflam-mation.

It was not until 22 years later that Ware et al (22) published the results of the first prospective, randomized controlled trial of steroids in FHF. In this trial of 15 patients, all with viral hepatitis, 11 were randomized to placebo and four to steroids. There were seven survivors in the placebo group and no survivors in the treatment group. Since the completion of this trial there have been three larger, prospective, randomized controlled trials published (23-25). All three studies concluded that steroids should no longer be used for patients suffering from FHF and may be associated with a higher mortality than the control patients. In summary, although steroids at first looked extremely promising, the results of controlled trials were not supportive. Thus, steroids have no role in the treatment of FHF except perhaps for the rare instance of FHF due to autoimmune hepatitis.

It was soon thereafter that a variety of treatment modalities were reported to be effective in isolated case reports, small uncontrolled clinical trials or both. Examples included hyperbaric oxygen, coenzymes, hemodialysis and peritoneal dialysis, exchange blood transfusions, extracorporeal whole liver perfusion and cross-circulation (26). Most promising was a trial by Trey et al (27) wherein five of seven FHF patients treated with exchange transfusions survived. Once again, however, when a prospective, randomized controlled trial was subsequently performed by Redeker and Yamahiro (28) the results were discouraging. No survival advantage was found in the 21 patients enrolled in their trial with exchange transfusions; in fact, there was a higher mortality in the treatment group.

Plasmapheresis has also been studied in several case reports. In $1970 \mathrm{Le}$ pore and Martel (29) published the results of this therapy in five patients. No survivors were reported, rendering plasmapheresis much like exchange transfusion.

\section{EXTRACORPOREAL WHOLE LIVER PERFUSION}

Extracorporeal whole liver perfusion and cross-circulation are theoretically appealing because they afford time for hepatic regeneration to occur. However, case reports using porcine livers, and less frequently human livers, for extracorporeal whole liver perfusion have not been too successful in improving survival (26). The technique has recently been looked at again by Chari and co-workers (30). They treated four patients, two with FHF due to hepatitis B virus (HBV), one with FHF due to ischemia and one with primary nonfunctional postliver transplant, with ex vivo pig liver perfusions. All had temporary neurological and biochemical improvements but only one survived long enough to be transplanted. There are the additional problems of technical difficulties, immune reactions and ethical issues. Indeed, cross-circulation has been associated with death (31) and could result in cross-infection of the healthy participant. Therefore, as with steroid therapy, time and further experience with these therapeutic options have proven them to be ineffective and/or inappropriate for treatment of FHF in humans.

\section{CHARCOAL HEMOPERFUSION}

The next putative advance in FHF management came with charcoal hemoperfusion. In the early 1970s, several investigators reported that charcoal hemoperfusion provided survival rates of 40 to $45 \%$ in FHF (32-36). Biocompatibility problems between the charcoal cartridges and platelets led Gazzard et al (36), at Kings College in London, to refine the treatment by adding prostacyclin (a prostaglandin analogue) to prevent platelet activation and subsequent hypotension. With this intervention, survival rates increased to $65 \%$ in patients with grade 3 coma $(37,38)$. Based on these results, a two-part prospective, randomized controlled trial was performed by the investigators from the same location (39). The trial involved 137 patients over three years. It was divided into trial A, patients with grade three coma who received either 5 or $10 \mathrm{~h}$ of hemoperfusion per day, and trial $\mathrm{B}$, patients with grade 4 coma who received either no perfusion or $10 \mathrm{~h}$ per day. The results of the trial led to the conclusion that enhanced survival was most likely the result of improvements in intensive care management rather than charcoal hemoperfusion. This was further illustrated by the fact that the survival rate in the acetaminophen group was the same in both trial $A$ and the no perfusion group of trial B (42.9 to $58.3 \%$ versus $55.6 \%$ ). Earlier work at the Kings College suggested that cerebral edema developed less often in patients treated earlier in grade 3 coma compared with patients started in grade 4 coma ( $49 \%$ versus $78 \%, \mathrm{P}<0.05)$ (38). However, their more recent work in a controlled setting was not able to confirm these results (39). In this trial, cerebral edema developed in 68.4 to $77.3 \%$ of patients in grade 3 coma. This result is not different from the $78 \%$ documented in their earlier work. Thus, there appears to be little role for charcoal hemoperfusion alone in patients with FHF. 


\section{HORMONES}

During the late 1970s insulin and glucagon therapy was studied. Earlier work with mice by Farivar et al (40) revealed that insulin and glucagon given immediately after inoculation with murine hepatitis virus resulted in a dramatic increase in survival. It was felt that this was the result of increased hepatic regeneration because previous trials had shown increased markers of hepatic regeneration in partially hepatectomized rats treated with insulin and glucagon (41). Moreover, Farivar and colleagues also documented increased DNA synthesis in treated rats compared with controls. Similar results were found in rats but not rabbits treated with chemical toxins known to induce FHF $(42,43)$. Based on these findings and retrospective reviews showing a survival advantage compared with historical controls $(44,45)$, two major prospective, randomized controlled trials were performed $(46,47)$. Once again, the results were discouraging. The two trials included 56 FHF patients in at least stage II encephalopathy. They found no differences in mortality between the hormone-treated and control groups. While a beta error due to the small sample sizes could not be excluded, the larger of the two trials found that mortality was higher in the treatment group (67\% versus $82 \%$ ), which renders this argument less relevant. Presently, insulin and glucagon cannot be considered useful in the treatment of FHF.

\section{PROSTAGLANDINS}

Prostaglandin therapy has recently received much attention. Positive findings have been reported with various types of prostaglandins in several models of FHF, including galactosamine and murine hepatitis virus-3 (48-59). The exact mechanism of this protective effect has not been determined. There is evidence that prostaglandins are cytoprotective (51-55), responsible for preservation of hepatic microcirculation (56), antiviral $(58,59)$, immunosuppressive (62-65), and able to preserve the blood brain barrier (66) and enhance hepatic regeneration $(67,68)$.
The first human studies with prostaglandins were reported by Sinclair et al $(69,70)$ who administered prostaglandin $\mathrm{E}_{1}$ ( $\mathrm{PGE}_{1}$ ) to $17 \mathrm{FHF}$ patients with various viral etiologies. This uncontrolled trial found survival to be $100 \%$ in patients presenting with grades 1 to 3 coma and $45 \%$ in patients presenting with grade 4 coma. Overall survival was $71 \%$, significantly better than historical controls (4-11). However, these promising results were not supported by two subsequent uncontrolled trials from France $(71,72)$. The French investigators found that PGE1 was ineffective in increasing the spontaneous survival rate for FHF due to either hepatitis $\mathrm{B}$ or drugs, or undetermined etiologies. The only randomized controlled trial to date was also unable to find an overall benefit to prostaglandin therapy (73). This trial, which involved PGE2, took place over three years and enrolled 41 patients. The survival rate in the treated group was $40 \%$ versus $38 \%$ in the placebo group. On subgroup analysis, the study revealed that PGE2 may be more effective if started within 10 days of FHF onset, particularly in patients suffering from FHF due to drugs or toxins. Obviously further controlled trials with larger numbers of patients are required to determine whether prostaglandin therapy has any role in the treatment of FHF in humans.

\section{INTERFERON}

Work has been done looking at the role of interferon in patients with FHF due to acute viral hepatitis. Patients with fulminant viral hepatitis have absent or grossly deficient amounts of interferon alpha and gamma (74). Based on these findings, Levin et al (75) treated 32 patients with FHF due to viral causes with interferon alpha ( $3 \mathrm{MU}$ intramuscularly for seven to 14 days). The overall survival rate in this uncontrolled trial was $50 \%$. Nine of $22 \mathrm{pa}$ tients $(41 \%)$ with grade 3 to 4 coma survived. However, the study population included 17 patients with hepatitis A virus (HAV) of whom nine survived, which mirrors the approximate survival rate for untreated $\operatorname{HAV}(4,7)$. Therefore, the $50 \%$ overall survival in the study by Levin and colleagues may reflect a patient population with a better prognosis rather than the effects of interferon per se. A trial similar to that of Levin et al was recently carried out by Sanchez-Tapias et al (76). They enrolled 12 patients with viral FHF mostly due to HBV/hepatitis delta virus or HBV alone. Only one patient had HAV. Ten of the 12 patients died despite the absence of grade 4 coma at the start of therapy (76). Poor results were also reported by Milazzo et al (77) in 16 patients treated with interferon beta intravenously. Thus, the use of interferon for viral-induced FHF can not be advocated.

\section{PUTRESCINE}

Putrescine is essential for hepatic regeneration (78-80). It is the product of the enzyme ornithine decarboxylase which is commonly used as a marker of hepatic regenerative activity (78). Nishiguchi et al (81) were able to demonstrate a marked improvement in hepatic DNA synthesis and a marked survival benefit ( $88 \%$ versus $40 \%$, $\mathrm{P}<0.01)$ in $\mathrm{D}$-galactosamine induced acute liver failure in rats treated with putrescine compared with untreated controls. Although putrescine may seem ideal to study in humans, it is not without concerns. Systemically administered putrescine may enhance cerebral edema (82) and may have an antidiuretic and nephrotoxic effect (83). Therefore, the search for the ideal agent continues.

\section{N-ACETYLCYSTEINE}

When administered within $10 \mathrm{~h}$, $\mathrm{N}$-acetylcysteine is the treatment of choice for acute acetaminophen overdose (84-87). Its use beyond $15 \mathrm{~h}$ after the overdose was discouraged by Prescott et al $(84,88)$ who found that despite its safety, late administration (given up to $24 \mathrm{~h}$ after an overdose [89]), does not prevent hepatic necrosis. However, these findings were not supported by Harrison et al (90); their retrospective analysis of 100 patients treated with $\mathrm{N}$-acetylcysteine between 10 and $36 \mathrm{~h}$ after ingestion found that mortality (37\% versus $58 \%$ ) and progression to grade 3 to 4 coma (51\% versus $75 \%$ ) were improved in the 
treatment group. Keays and associates (91), in a prospective, randomized trial of 29 patients, also found that $\mathrm{N}$-acetylcysteine given late after the overdose (36 h or more) was associated with a marked improvement in survival $(64 \%$ versus $20 \%$ ). Finally, the most recent prospective, randomized controlled trial using $\mathrm{N}$-acetylcysteine in established FHF due to acetaminophen (mean 53 to $56 \mathrm{~h}$ postingestion) revealed that $\mathrm{N}$-acetylcysteine was effective in improving survival (48\% versus 20\%), reducing the incidence of cerebral edema $(40 \%$ versus $68 \%$ ) and reducing the incidence of hypotension requiring inotropic support (48\% versus 80\%) (92). However, in many of the late treatment trials, tests of hepatic function, in particular the prothrombin time, were similar in both groups at the end of treatment, and rates of improvement were also similar. This finding led the group at Kings College (92) to suggest that it is not the glutathione repleting properties of $\mathrm{N}$-acetylcysteine that improve survival but rather its effects on oxygen delivery and consumption.

Based on the premise that FHF is associated with covert tissue hypoxia (93), Harrison et al (94) studied the role of $\mathrm{N}$-acetylcysteine on the hemodynamics and oxygen transport in patients with acetaminophen- and nonacetaminophen-induced FHF. This trial revealed that $\mathrm{N}$-acetylcysteine in established FHF improves oxygen delivery, cardiac index and oxygen consumption in all forms of FHF and may be related to improvements in the microcirculation as a result of increased endothelium-derived relaxing factor (nitric oxide). Furthermore, $\mathrm{N}$-acetylcysteine improves cerebral bloodflow and cerebral metabolic rate for oxygen which, in turn, may account for the reduced incidence of cerebral edema in patients suffering from FHF treated with late $\mathrm{N}$-acetylcysteine (95). In summary, N-acetylcysteine appears to have a lot of promise for the treatment of FHF due to acetaminophen and perhaps all causes of FHF. Again, it must be stressed that more controlled trials are needed to confirm these initial promising studies. However, the relative safety of this agent, its posi- tive effects on oxygen delivery and consumption, and its proven effectiveness in acetaminophen-induced FHF make $\mathrm{N}$-acetylcysteine a worthwhile therapeutic option in the management of FHF patients regardless of the cause.

\section{OTHER AGENTS}

Other agents that have been tested recently in the treatment of FHF include hepatic stimulatory substance, antithrombin III (AT III) and antiendotoxin monoclonal antibodies. Hepatic stimulatory substance alone and with other presumed enhancers of hepatic regeneration (insulin, transforming growth factor-alpha and insulinlike growth factor II) was ineffective in altering the survival rates of 62 dogs with FHF (96). AT III infusions in rats with FHF due to dimethylnitrosamine improved serum bilirubin levels, prothrombin time, alanine aminotransferase levels, and reduced the degree of histological damage at $24 \mathrm{~h}$ (97). However, in an uncontrolled trial of $26 \mathrm{hu}$ mans with FHF due to various causes, a $27 \%$ survival rate was reported using AT III, not an improvement over historical controls (98). A randomized controlled trial with AT III remains to be performed. In one case report, Manthous et al (99) described the results of monoclonal anti-endotoxin antibody treatment in a patient with acute hepatitis A. The trial was based on previous data from patients with cirrhosis and acute liver failure where hemodynamic parameters similar to septic shock and increased endotoxin levels were reported (100-102). The patient described in the report from Manthous and co-workers showed a significant improvement in hemodynamic parameters following anti-endotoxin antibody administration. Unfortunately, the patient died 10 days later from intractable status epilepticus. Before his death he had remained hemodynamically stable and off all inotropes. Obviously, more data on anti-endotoxin antibody are required.

\section{ARTIFICIAL SUPPORT SYSTEMS}

Because of the early failures associated with artificial support systems, much work has recently addressed the development of a bioartificial liver support system and hepatocyte transplantation as either bridges to transplantation or interventions that will allow time for spontaneous recovery from FHF. As presently designed, these devices offer more than other treatment modalities. Specifically, they have the ability to both clear and metabolize toxic compounds as well as synthesize products that are essential for the recovery process. Intact hepatocytes have been stressed as being essential in liver support systems (103-106). Extracorporeal devices come in various forms. Some implement primary hepatocytes of nonhuman species $(106,107)$, while others employ cultured human hepatoblastoma cells $(108,109)$. Some devices consist of hollow fibre cartridges with hepatocytes lining the capillary tubing (106-109), while others are suspensions of encapsulated hepatocytes (110). Despite the various designs being studied, the bioartificial liver is essentially made of the same components. These components are live hepatocytes, a barrier to separate the patient's blood cells from the hepatocytes, and a mechanism for perfusion of the patient's whole blood or plasma over the cells (111). These devices are just now being tried in humans with FHF. While the results are encouraging, they are still confined to limited case reports. Therefore, randomized trials will be required to assess their role in FHF definitively.

\section{ISOLATED HEPATOCYTE TRANSPLANTATION}

Isolated hepatocyte transplantation for FHF is by no means a new therapeutic modality. It has been shown in animal models of FHF to improve survival regardless of whether the cells are allogeneic or xenogeneic (112-118). The process usually involves intraperitoneal implantation of free hepatocytes, coated microcarrier beads, spheroid hepatocyte aggregates, hepatocytes immobilized on porous, biodegradable polymeric substrates or microencapsulated gel droplets. Immunosuppression is required to maintain viability by preventing rejection of the cells. 
The microencapsulation technique may provide a means of transplanting hepatocytes in the absence of immunosuppression because the cells are sequestered from the host immune system. The technique has yet to be reported in humans. Much work remains to be done in this area of research.

\section{CONCLUSIONS}

Most of the treatment modalities, short of transplantation, have been fraught with initial success in case reports and uncontrolled trials, only to be proven ineffective in larger randomized control studies. However, for the most part, even the large controlled studies REFERENCES

1. Trey C, Davidson CS. The management of fulminant hepatic failure. In: Popper H, Schaffner F, eds. Progress in liver diseases, vol III. New York: Grune and Stratton, 1970:282-98.

2. Bernuau J, Rueff B, Benhamov J. Fulminant and subfulminant liver failure: definitions and causes. Semin Liver Dis 1986;6:97-106.

3. Gimson AE, O'Grady J, Ede RJ, Portmann B, Williams R. Late onset hepatic failure: clinical, serological and histological features. Hepatology 1986;6:288-94.

4. Lee WM. Acute liver failure. N Engl J Med 1993;329:1862-72.

5. Katelaris PH, Jones DB. Fulminant hepatic failure. Med Clin North Am 1989;73:955-70.

6. Kramer DJ, Aggarwal S, Martin M, et al. Management options in fulminant hepatic failure. Transplant Proc 1991;23:1895-8.

7. Williams R, Gimson AES. Intensive liver care and management of acute hepatic failure. Dig Dis Sci 1991;36:820-6.

8. Sinclair S, Wakefield A, Levy G. Fulminant hepatitis. Springer Semin Immunopathol 1990;12:33-45.

9. Munoz SJ. Difficult management problems in fulminant hepatic failure. Semin Liver Dis 1993;13:395-413.

10. Fingerote RJ, Bain VG. Fulminant hepatic failure. Am J Gastroenterol 1993;88:1000-10.

11. Wiesner RH. Acute fulminant hepatic failure. Transplant Proc 1991;23:1892-4.

12. Hughes RD, Wendon J, Gimson AES. Acute liver failure. Gut 1991;(Suppl):S86-91.

13. Rakela J, Perkins JD, Gross JB, et al. Acute hepatic failure: the emerging role of orthotopic liver transplantation. Mayo Clin Proc 1989;64:424-8.

14. Campbell DA Jr, Ham JM, McCurry do not contain sufficient patient numbers to exclude a beta error. Multicentre or multinational trials may represent the only solution to this problem; ideally, such trials would also allow for stratification of patients based on etiology, coma grade, age and time interval from onset to encephalopathy.

What does the future hold? Most certainly research will continue with the more promising agents including $\mathrm{N}$-acetylcysteine and perhaps prostaglandins. The results of ongoing studies with bioartificial livers and hepatocyte transplantation are eagerly awaited. More effort is needed to identify agents that enhance and inhibit hepatic re-

KR, Lucey MR, Turcotte JG, Merion

RM. Liver transplant for fulminant

hepatic failure. Am Surg

1991;57:546-9.

15. Williams R, Wendon J. Indications for orthotopic liver transplantation in fulminant hepatic failure. Hepatology 1994;20:5S-10S.

16. Colbert JW, Holland JA, Heissler I, Knowlton M. The use of ACTH in acute viral hepatitis. N Engl J Med 1951;245:172-7.

17. Katz R, Velasco M, Klinger J, Alessandri H. Corticosteroids in the treatment of acute hepatitis in coma. Gastroenterology 1962;42:258-65.

18. Ripkin H, Marks LJ, Hammerman DJ, Blumenthal MJ, Weiss A, Weingarten R. Use of corticotropin and cortisone in acute homologous serum hepatitis. Arch Intern Med 1952;89:32-40.

19. Evans AS, Sprinz H, Nelson RS. Adrenal hormone therapy in viral hepatitis III. The effect of ACTH and cortisone in severe and fulminant cases. Ann Intern Med 1953;38:1148-59.

20. Katz R, Velasco M, Klinger J, Alessandri H. Corticosteroids in the treatment of acute hepatitis in coma. Gastroenterology 1962;42:258-65.

21. Ducci H, Katz R. Cortisone, ACTH and antibiotics in fulminant hepatitis. Gastroenterology 1952;21:357-74.

22. Ware AJ, Jones RE, Shorey JW, Burton C. A controlled trial of steroid therapy in massive hepatic necrosis. Am J Gastroenterol 1974;62:130-3.

23. Gregory PB, Knauer M, Kempson RL, Miller R. Steroid therapy in severe viral hepatitis: a double-blind, randomized trial of methylprednisolone versus placebo. N Engl J Med 1976;294:681-7.

24. European Association for the Study of the Liver. Randomized trial of steroid therapy in acute liver failure: a report generative activity. Finally, a combination of some of the above therapeutic modalities may be what is required to improve survival rates further in FHF patients. In the interim, good supportive management and possibly $\mathrm{N}$-acetylcysteine administration with early transfer to liver transplant units must remain the treatment of choice for patients suffering from FHF.

ACKNOWLEDGEMENTS: Dr Kaita is the recipient of a Roche Canada/University of Manitoba Hepatology Fellowship Award.

from the European Association for the Study of the Liver. Gut 1979;20:620-3.

25. Rakela J, Mosley JW, Edwards VM, Govindarajan S, Alpert E, and the Acute Hepatic Failure Study Group. A double-blind, randomized trial of hydrocortisone in acute hepatic failure. Dig Dis Sci 1991;36:1223-8.

26. Benhamou JP, Rueff B, Sicot C. Severe hepatic failure: a critical study of current therapy. In: Orlandi F, Jezequel AM, eds. Liver and Drugs. New York: Academic Press, 1972:213-28.

27. Trey C, Burns DG, Saunders SJ. Treatment of hepatic coma by exchange blood transfusion. N Engl J Med 1966;274:473-81.

28. Redeker AG, Yamahiro HS. Controlled trial of exchange transfusion therapy in fulminant hepatitis. Lancet 1973;i:3-6.

29. Lepore MJ, Martel AJ. Plasmapheresis with plasma exchange in hepatic coma: methods and results in five patients with acute fulminant hepatic necrosis. Ann Intern Med 1970;72:165-74.

30. Chari RS, Collins BH, Magee JC, et al. Brief report: treatment of hepatic failure with ex vivo pig-liver perfusion followed by liver transplantation. N Engl J Med 1994;331:234-7.

31. Muller JM, Guignier M, Couderc P, et al. Methods of assisting the liver. A critical study of present-day possibilities in the treatment of acute liver insufficiency of viral or toxic origin. Ann Gastroenterol Hepatol 1971;7:25-52.

32. Chang TMS. Hemoperfusion over microencapsulated adsorbent in a patient with hepatic coma. Lancet 1973;ii:1371-2.

33. Gelfand MC, Winchester JF, Knepshield JH, Cohan SL, Schreiner GE. Biochemical correlations of reversal of hepatic coma treated with charcoal hemoperfusion. Trans Am 
Soc Artif Intern Organs

1978;24:239-42.

34. Takahashi Y. Acute hepatic failure - in special relation to treatment. Jpn J Med 1983;22:140-5.

35. Kennedy HJ, Greaves M, Triger DR. Clinical experience with the use of charcoal hemoperfusion: is prostacyclin required? Life Support Syst 1985;3:115-22.

36. Gazzard BG, Portmann B, Weston MJ, et al. Charcoal haemoperfusion in the treatment of fulminant hepatic failure. Lancet 1974;i:1301-7.

37. Gimson AES, Langley PG, Hughes $\mathrm{RD}$, et al. Prostacyclin to prevent platelet activation during charcoal haemoperfusion in fulminant hepatic failure. Lancet 1980;i:173-5.

38. Gimson AES, Braude S, Mellon PJ, Canalese J, Williams R. Earlier charcoal haemoperfusion in fulminant hepatic failure. Lancet 1982;ii:681-3.

39. O'Grady JG, Gimson AES, O'Brien CJ, Pucknell A, Hughes RD, Williams R. Controlled trials of charcoal hemoperfusion and prognostic factors in fulminant hepatic failure. Gastroenterology 1988;94:1186-92.

40. Farivar M, Wands JR, Isselbacher KJ, Bucher NLR. Effect of insulin and glucagon on fulminant murine hepatitis. N Engl J Med 1976;295:1517-9.

41. Bucher NLR, Swaffield MN. Regulation of hepatic regeneration in rats by synergistic action of insulin and glucagon. Proc Natl Acad Sci USA 1975;72:1157-60.

42. Fujiwara K, Ogata I, Mishiro Y, et al. Glucagon and insulin for the treatment of hepatic failure in dimethylnitrosamine-intoxicated rats. Scand J Gastroenterol 1988;23:567-73.

43. Minuk GY, Sherman TA, Shaffer EA, Kelly SK. A comparative study of the effects of insulin/glucagon infusions, parenteral amino acids and high dose corticosteroids on survival in a rabbit model of acute fulminant hepatitis. Hepatology 1986;6:73-8.

44. Narendranathan M, Nandini KK, Balakrishnan V. A trial of glucagon in fulminant hepatitis. J Assoc Physicians India 1985;33:219-220.

45. Oka H, Okita K, Fujiwara K. Glucagon and insulin therapy in fulminant hepatic failure in Japan. In: Pizaco J, ed. Glucagon in Gastroenterology and Hepatology. Lancaster: MTP Press, 1982:171-8.

46. Woolf GM, Redeker AG. Treatment of fulminant hepatic failure with insulin and glucagon: a randomized, controlled trial. Dig Dis Sci 1991;36:92-6.

47. Harrison PM, Hughes RD, Forbes A,
Portmann B, Alexander GJM, Williams R. Failure of insulin and glucagon infusion to stimulate liver regeneration in fulminant hepatic failure. J Hepatol 1990;10:332-6.

48. Rober A, Ruwart MJ. Effects of prostaglandins on the digestive system. In: Lee JB, ed. Prostaglandins. New York: North Holland, 1982:113-76.

49. Alp MH, Hickman R. The effect of prostaglandins, branched-chain amino acids and other drugs on the outcome of experimental acute porcine hepatic failure. J Hepatol 1987;4:99-107.

50. Araki H, Lefer AM. Cytoprotective actions of prostacyclin during hypoxia in the isolated perfused cat liver. Am J Physiol 1980;238:H176-81.

51. Mizoguchi Y, Tsutsui H, Miyajima K, et al. The protective effects of prostaglandin E1 in an experimental massive hepatic cell necrosis model. Hepatology 1987;7:1184-8.

52. Stachura J, Taranwski A, Ivey KJ et al. Prostaglandin protection of carbon tetrachloride-induced liver cell necrosis in the rat. Gastroenterology 1981;81:211-7.

53. Makowka L, Falk RE, Cohen MM, et al. Protective effect of 16,16dimethyl prostaglandin E2 on acute ethanol-induced inhibition of hepatic regeneration. Surg Forum 1982;33:183-6.

54. Noda Y, Hughes RD, Williams R. Effect of prostacyclin (PGI2) and a prostaglandin analogue BW $245 \mathrm{C}$ on galactosamine-induced hepatic necrosis. J Hepatol 1986;2:53-64.

55. Lim SP, Andrews FJ, Christophi C, O'Brien PE. Misoprostol hepatoprotection against ischemiareperfusion-induced liver injury in the rat. Dig Dis Sci 1992;37:1275-81.

56. Lim SP, Andrews FJ, Christophi C, O'Brien PE. Microvascular changes in liver after ischemia-reperfusion injury: protection with misoprostol. Dig Dis Sci 1994;39:1683-90.

57. Ogawa M, Mori T, Mori Y, et al. Inhibitory effects of prostaglandin E1 on $T$ cell mediated cytotoxicity against isolated mouse liver cells Gastroenterology 1988;94:1024-30.

58. Zhou M, Chang TMS. Effects of polylactic acid microcapsules containing prostaglandin E2 on the survival rates of grade II coma galactosamine induced fulminant hepatic failure rats. Biomater Artif Cells Artif Organs 1987;15:549-58.

59. Abecassis M, Falk JA, Makowka L, Dindzans VJ, Falk RE, Levy GA. 16,16 dimethyl prostaglandin E2 prevents the development of fulminant hepatitis and blocks the induction of monocyte/macrophage procoagulant activity after murine hepatitis virus strain 3 infection. J Clin Invest 1987;80:881-9.

60. Santoro MG, Benedetto A, Zaniratti S, Garaci E, Jaffe GM. The relationship between prostaglandins and virus replication: endogenous prostaglandin synthesis during infection and the effect of exogenous PGA on virus production in different cell lines and in persistently infected cells. Prostaglandins 1983;25:353-63.

61. Giron DJ. Inhibition of viral replication in cell cultures treated with prostaglandin E1 (41390). Proc Soc Exp Biol Med 1982;170:25-8.

62. Taffet SM, Russel SW. Macrophagemediated tumor cell killing: regulation of expression of cytolytic activity by prostaglandin E. J Immunol 1981;126:424-8.

63. Snyder DS, Beller DI, Unanue ER. Prostaglandins modulate macrophage Ia expression. Nature 1982;299:163-8.

64. Tripp CS, Wyche A, Unanue ER, Needleman P. The functional significance of the regulation of macrophage Ia expression by endogenous arachidonate metabolites in vitro. J Immunol 1986;137:3915-20.

65. Rappaport RS, Dodge GR. Prostaglandin E inhibits the production of human interleukin 2. J Exp Med 1982;155:943-8.

66. Dixit V, Chang TMS. Effects of prostaglandin E2 on brain edema and liver histopathology in a galactosamine-induced fulminant hepatic failure rat model. Biomater Artif Cells Artif Organs 1987;15:559-73.

67. Andreis PG, Whitfield JF, Armato U. Stimulation of DNA synthesis and mitosis of hepatocytes in primary cultures on neonatal rat liver by arachidonic acid and prostaglandins. Exp Cell Res 1981;134:265-72.

68. Urakawa T, Azumi Y, Nagahata Y, et al. Study of 16,16-dimethyl prostaglandin E2 for prevention of stress ulcer after hepatectomy of experimental cirrhotic liver and its influence on hepatic regeneration. Scand J Gastroenterol 1990;25:647-55.

69. Sinclair SB, Greig PD, Blendis LM, et al. Biochemical and clinical response of fulminant viral hepatitis to administration of prostaglandin E: a preliminary report. J Clin Invest 1989;84:1063-9.

70. Sinclair SB, Levy GA. Treatment of fulminant viral hepatic failure with prostaglandin E: a preliminary report. Dig Dis Sci 1991;36:791-800.

71. Bernuau J, Babany G, Bourliere M, et al, and the Association Francaise pour l'Etude du Foie. Prostaglandin E1 
(PGE1) has no beneficial effect in patients with either severe or fulminant hepatitis B. Hepatology 1990;12:875. (Abst)

72. Bernuau J, Babany G, Pauwels A, et al, and the Association Francaise pour l'Etude du Foie. Prostaglandin E1 (PGE1) has no beneficial effect in patients with either severe or fulminant hepatitis due to drugs or of undetermined etiology. Hepatology 1990;12:931. (Abst)

73. Sheiner P, Sinclair S, Greig P, Logan A, Blendis LM, Levy G. A randomized control trial of prostaglandin E2 (PGE2) in the treatment of fulminant hepatic failure (FHF). Hepatology 1992;16:88a. (Abst)

74. Levin S, Hahn T. Interferon deficiency syndrome. Clin Exp Immunol 1985;60:267-73.

75. Levin S, Leibowitz E, Torten J, Hahn $\mathrm{T}$. Interferon treatment in acute progressive and fulminant hepatitis. Isr J Med Sci 1989;25:364-72.

76. Sanchez-Tapias JM, Mas A, Costa J, et al. Recombinant alpha $2 c$-interferon therapy in fulminant viral hepatitis. J Hepatol 1987;5:205-10.

77. Milazzo F, Galli M, Fassio PG, et al. Attempted treatment of fulminant viral hepatitis with human fibroblast interferon. Infection 1985;13:130-3.

78. Luk GD. Essential role of polyamine metabolism in hepatic regeneration; inhibition of deoxyribonucleic acid and protein synthesis and tissue regeneration by difluoromethylornithine in the rat. Gastroenterology 1986;90:1261-7.

79. Poso H, Pegg AE. Effect of alpha-difluoromethylornithine on polyamine and DNA synthesis in regenerating rat livers: reversal of inhibition of DNA synthesis by putrescine. Biochem Biophys Acta 1982;696:179-86.

80. Minuk GY, Gauthier T, Gaharie A, Murphy L. The effect of GABA on serum and hepatic polyamine concentrations after partial hepatectomy in rats. Hepatology 1991;14:685-9.

81. Nishiguchi S, Kuroki T, Takeda T, et al. Effects of putrescine on D-galactosamine-induced acute liver failure in rats. Hepatology 1990;12:348-53.

82. Koenig H, Goldstone AD, Lu CY. Blood-brain barrier breakdown in cold-injured brain is linked to a biphasic stimulation of ornithine decarboxylase activity and polyamine synthesis: both are coordinately inhibited by verapamil, dexamethasome, and aspirin. J Neurochem 1989;52:101-9.

83. Genedani S, Bernardi M, Tagliavine S,
Botticelli H, Bertolini A. Antidiuretic and nephrotoxic effects of putrescine in rats. Pharmacol Res 1991;23:95-103.

84. Prescott LF, Illingworth RN, Critchley JAJH, Stewart MJ, Adams RD, Proudfoot AT. Intravenous $\mathrm{N}$-acetylcysteine: the treatment of choice for paracetamol poisoning. BMJ 1979;ii:1097-100.

85. Smilkstein MJ, Knapp GL, Kulig KW, Rumack BH. Efficacy of oral $\mathrm{N}$-acetylcysteine in the treatment of acetaminophen overdose. N Engl J Med 1988;319:1557-62.

86. Rumack BH, Peterson RC, Koch GC, Amara IA. Acetaminophen overdose: 662 cases with evaluation of oral acetylcysteine treatment. Arch Intern Med 1981;141:380-5.

87. Davis M. Protective agents for acetaminophen overdose. Semin Liver Dis 1986;6:138-47.

88. Prescott LF. Paracetamol overdosage: pharmacological considerations and clinical management. Drugs 1983;25:290-314.

89. Parker D, White JP, Paton D, Routledge PA. Safety of late acetylcysteine treatment in paracetamol poisoning. Hum Exp Toxicol 1990;9:25-7.

90. Harrison PM, Keays R, Bray GP, Alexander GJM, Williams R. Improved outcome of paracetamol-induced fulminant hepatic failure by late administration of acetylcysteine. Lancet 1990;335:1572-3.

91. Keays RT, Gove C, Forbes A, Alexander GJM, Williams R. Use of late $\mathrm{N}$-acetylcysteine in severe paracetamol overdose. Gut 1989;30:1512A. (Abst)

92. Keays R, Harrison PM, Wendon JA, et al. Intravenous acetylcysteine in paracetamol induced fulminant hepatic failure: a prospective controlled trial. BMJ 1991;303:1026-9.

93. Bihari D, Gimson AES, Waterson M, Williams R. Tissue hypoxia during fulminant hepatic failure. Crit Care Med 1985;13:1034-9.

94. Harrison PM, Wendon JA, Gimson AES, Alexander GJM, Williams R. Improvement by acetylcysteine of hemodynamics and oxygen transport in fulminant hepatic failure. $\mathrm{N}$ Engl J Med 1991;324:1852-7.

95. Wendon JA, Harrison PM, Keays R, Williams R. Cerebral blood flow and metabolism in fulminant liver failure. Hepatology 1994;19:1407-13.

96. Francavilla A, Azzarone A, Carrieri G, et al. Administration of hepatic stimulatory substance alone or with other liver growth factors does not ameliorate acetaminophen-induced liver failure. Hepatology 1993;17:429-33.
97. Fujiwara K, Ogata I, Ohta Y, et al. Intravascular coagulation in acute liver failure in rats and its treatment with antithrombin III. Gut 1988;29:1103-8.

98. Fujiwara K, Okita K, Akamatsu K, et al. Antithrombin III concentrate in the treatment of fulminant hepatic failure. Gastroenterol Jpn 1988;23:423-7.

99. Manthous CA, Schmidt GA, Kemp R, Wood LDH. Fulminant hepatic failure treated with anti-endotoxin antibody. Crit Care Med 1992;20:1617-9.

100. Trewby PN, Williams R. Pathophysiology of hypotension in patients with fulminant hepatic failure. Gut 1977;18:1021-6.

101. Bigatello LM, Beatman S, Faltoci L. Endotoxemia, encephalopathy and mortality in cirrhotic patients. Am J Gastroenterol 1987;82:11-5.

102. Lumdsen AB, Henderson J, Kutner M. Endotoxin levels measured by chromogenic assay in portal, hepatic and peripheral venous bloods in patients with cirrhosis. Hematology 1988;8:232-6.

103. Yanagi K, Ookawa K, Shuichi M, Oshima N. Performance of a new hybrid artificial liver support system using hepatocytes entrapped within a hydrogel. Trans Am Soc Artif Intern Organs 1989;35:570-2.

104. Arnaout WS, Moscioni AD, Barbour RL, Demetriou AA. Development of bioartifical liver: bilirubin conjugation in Gunn rats. J Surg Res 1990;48:379-82.

105. Matsumura KN, Guevara GR, Huston $\mathrm{H}$, et al. Hybrid bioartificial liver in hepatic failure: preliminary clinical report. Surgery 1987;101:99-103.

106. Rozga J, Williams F, Ro M, et al. Development of a bioartificial liver: properties and function of a hollow-fiber module inoculated with liver cells. Hepatology 1993;17:258-65.

107. Neuzil DF, Rozga J, Moscioni AD, et al. Use of a novel bioartificial liver in a patient with acute liver insufficiency. Surgery 1993;113:340-3.

108. Sussman NL, Chong MG, Koussayer T, et al. Reversal of fulminant hepatic failure using an extracorporeal liver assist device. Hepatology 1992;16:60-5.

109. Kelly JH, Sussman NL. The hepatic extracorporeal liver assist device in the treatment of fulminant hepatic failure. ASAIO J 1994;40:83-5.

110. Matthew HWT, Basu S, Peterson WD, Salley SO, Klein MD. Performance of plasma-perfused, microencapsulated hepatocytes: prospects for extracorporeal liver support. J Pediatr Surg 1993;28:1423-8.

111. Nyberg SL, Peshwa MV, Payne WD, 
Hu W, Cerra FB. Evolution of the bioartificial liver: the need for randomized clinical trials. Am J Surg 1993;166:512-8.

112. Sutherland DER, Numate M, Matas AJ, Simmons RL, Najaran JS. Hepatocellular transplantation in acute liver failure. Surgery 1977;82:124-32.

113. Sommer BG, Sutherland DE, Matas DJ, Simmons RL, Najaran JS. Hepatocellular transplantation for treatment of D-galactosamine-induced acute liver failure in rats. Transplant Proc 1979;11:578-84.

114. Makowka L, Rotstein LE, Falk RE, et al. Reversal of toxic and anoxic induced hepatic failure by syngeneic, allogeneic and xenogeneic hepatocyte transplantation. Surgery 1980;88:2243-53.

115. Sommer BG, Sutherland DER, Simmons RL, Najaran JS. Hepatocellular transplantation for experimental ischemic acute liver failure in dogs. J Surg Res 1980;29:319-25.

116. Miyazaki M, Mokowka L, Falk RE, Falk JA, Falk W, Ventura D. Reversal of lethal, chemotherapeutically induced acute hepatic necrosis in rats by regenerating liver cytosol. Surgery 1983;94:142-50.
117. Minato M, Houssin D, Demma I, et al. Transplantation of hepatocytes for treatment of surgically induced acute hepatic failure in the rat. Eur Surg Res 1984;16:162-9.

118. Demetriou A, Reisner A, Sanchez J, Levenson SM, Moscioni AD, Roy Chowdhury J. Transplantation of microcarrier-attached hepatocytes into 90\% partially hepatectomized rats. Hepatology 1988;8:1006-9. 


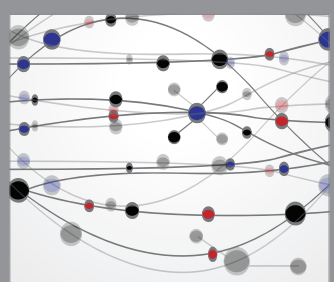

The Scientific World Journal
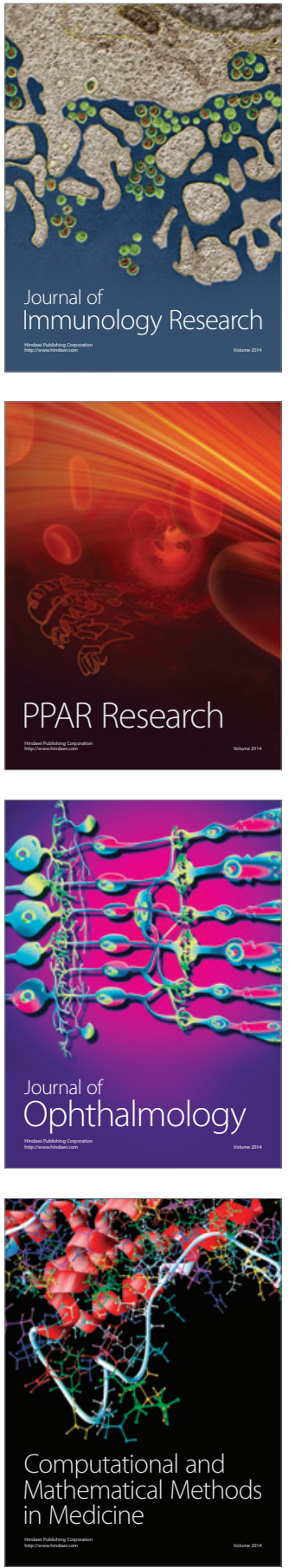

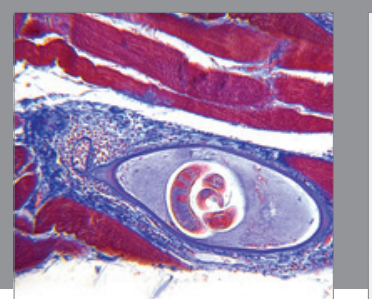

Gastroenterology Research and Practice

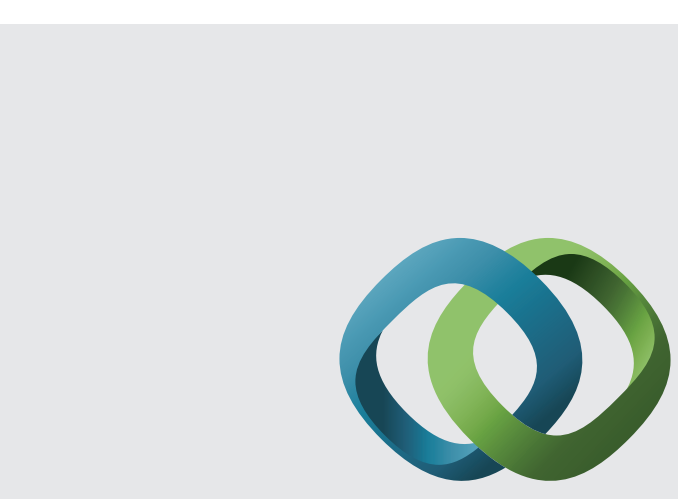

\section{Hindawi}

Submit your manuscripts at

http://www.hindawi.com
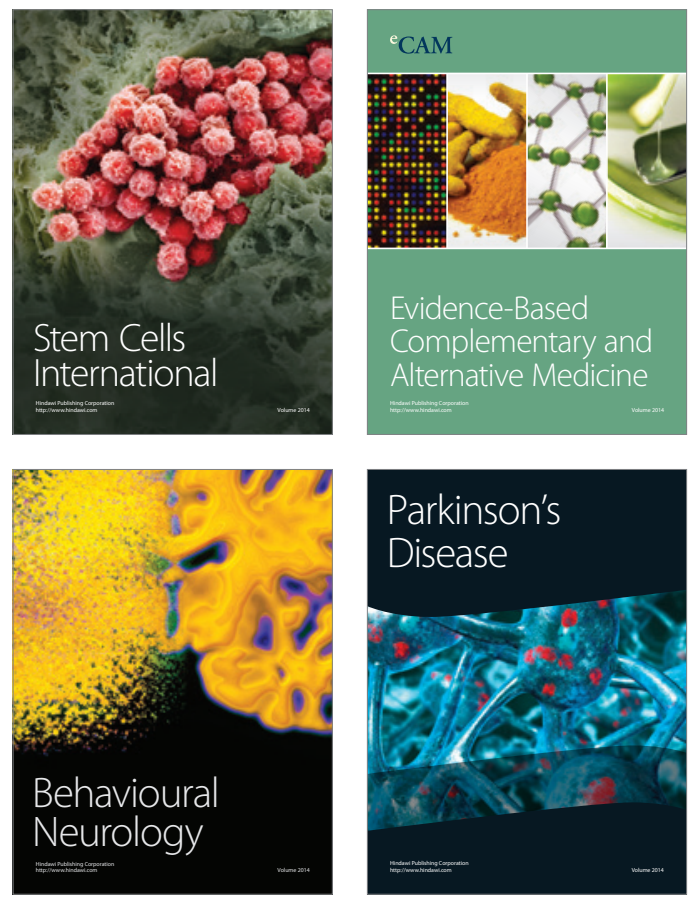
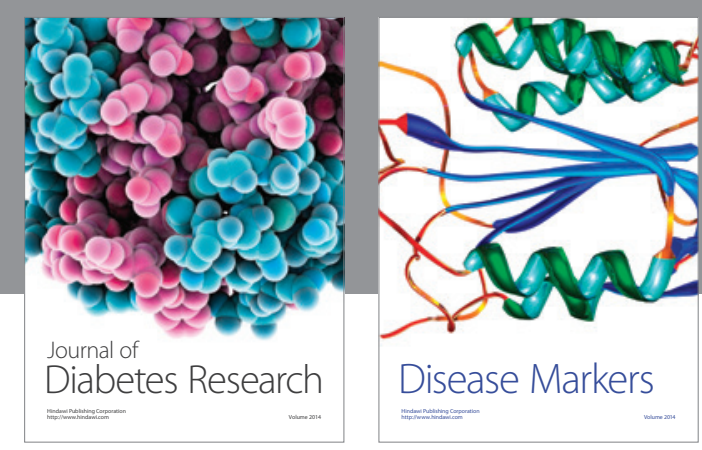

Disease Markers
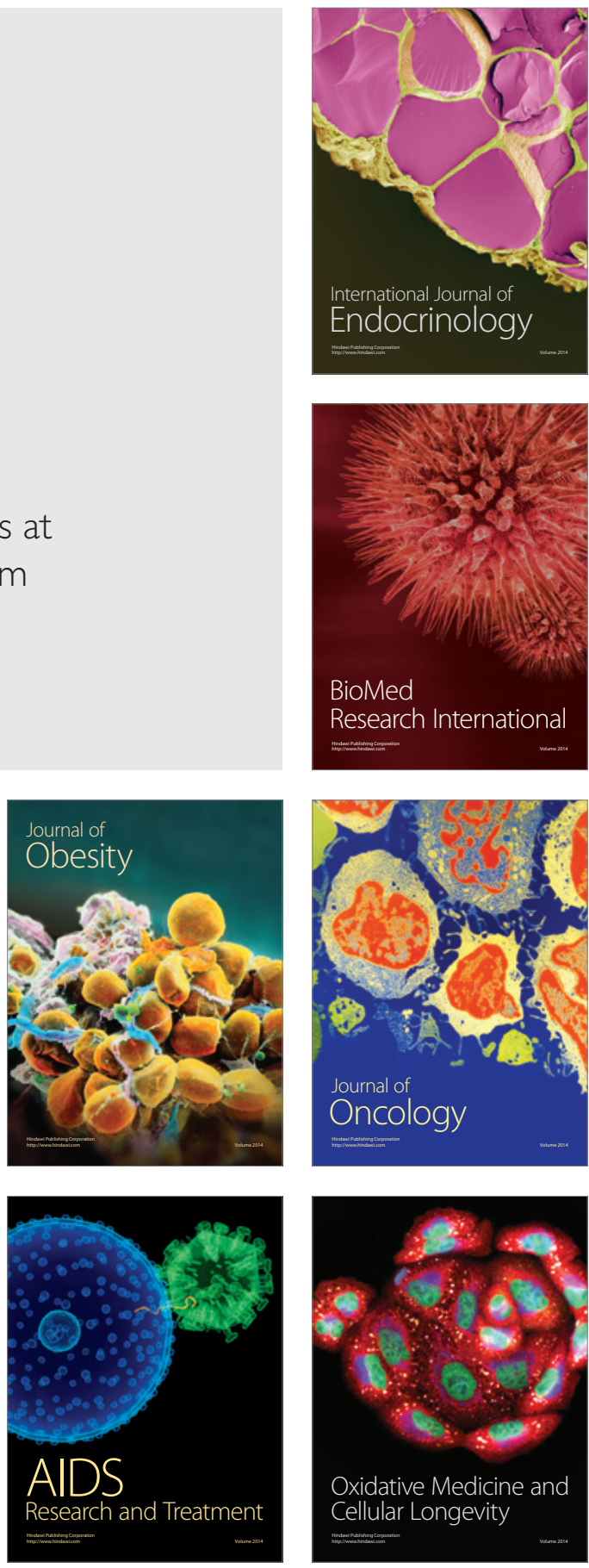